\title{
A V4-EK BIZTONSÁG- ÉS VÉDELEMPOLITIKÁJA - NEMZETI ÉS SZÖVETSÉGESI KIHÍVÁSOK A TAGORSZÁGOKBAN
}

\section{V4 SECURITY AND DEFENSE POLICY - NATIONAL AND ALLIED CHALLENGES IN MEMBER STATES}

\author{
Hronyecz Erika
}

Nemzeti Közszolgálati Egyetem - Budapest, Magyarország, hronyecz.erika@gmail.com

\begin{abstract}
Making the common European security and defense policy more effective starts at the state level. It is of paramount importance that the member states of the respective federations can able to demonstrate modern forces with high level of compatibility and qualification and along with that the use of these national forces at allied level should be possible without major obstacles. In this publication, the author presents the main historical points of the defense policy of the Visegrad Cooperation (V4) countries, and in this context the steps and efforts of the force to respond to new types of security challenges.
\end{abstract}

Keywords: Visegrad Group, security policy, defense policy, alliance, challenges.

\section{Összefoglalás}

A közös európai biztonság és a védelempolitika hatékonyabbá tétele az államok szintjén kezdődik. Kiemelten fontos, hogy az adott szövetségek tagországai olyan modern, kompatibilitás és képzettség tekintetében magas szinten teljesítő haderőt tudjanak felmutatni, melyek alkalmazása nemzetközi szintű összefogást igénylő probléma megoldása, illetve elhárítása esetén nem jelenti akadályát a hatékony fellépésnek. Jelen közleményben a szerző a visegrádi együttműködés (V4) országainak védelempolitikájának főbb történelmi pontjait, illetve ezzel összefüggésben az új típusú biztonsági kihívásokra adott haderőfejlesztési lépéseit, erőfeszítéseit mutatja b.

Kulcsszavak: Visegrádi Csoport, biztonságpolitika, védelempolitika, szövetség, kihívások.

\section{A biztonsági tényezők és a védelem- politika alakulása a visegrádi csoport fennállása óta}

A rendszerváltás után a kelet-közép-európai térség államai számára a gazdasági és szociális biztonság alapvető fontossággal bírt, és ennek reformálásra, fejlesztésére, hosszú távon történő stabilizálására elsődleges megoldásként az Európai Unióhoz mint gazdasági és értékközösséghez történő csatlakozást látták. De mindezen tényezők mellett nem lehetett figyelmen kívül hagyni a katonai biztonságot sem, mely szintén szenzitív állapotban volt a korábbi szocialista rendszer felbomlása után. A varsói szerződés 1991-ben történt felszámolását követően a tagországok egységesen arra törekedtek, hogy teljesítsenek minden olyan feltételt, amely hozzájárul ahhoz, hogy a lehető legrövidebb időn belül csatlakozhassanak az Észak-atlanti Szerződés Szervezetéhez. Ebben az esetben nemcsak a Nyugat felé való nyitás ösztönözte az államokat. A régió országai tudatában voltak annak, hogy egy adott külső támadás esetén önállóan nem lennének képesek megvédeni területüket, nemzetüket, szükségszerű a szövetségesi szintű szerveződés megléte. Nyolc évvel a VSZ megszűnése után, 1999. március 12-én Lengyelország, Csehország és Magyarország a NATO tagja lett, 2004-ben pedig - 
más kelet-európai volt szocialista országok mellett - Szlovákia is belépett a szervezetbe.

A '90-es években az euroatlanti integrációs folyamat müködtetése mellett, illetve annak felgyorsítása és a lehetőségekhez mérten zökkenőmentes végbemenetelének érdekében Lengyelország, Csehország, Szlovákia (1993. január 1-ig Csehszlovákia) és Magyarország együttesen szükségét érezte egy szűkebb, régión belüli összefogásnak, melyet a Visegrádi Együttműködés keretén belül valósítottak meg.

A visegrádi csoport közel 30 éves fennállása alatt több fázison is átesett az együttműködést tekintve. A kezdeti sikereket és lendületet hamar felváltották a kudarcok, a széthúzás és az egymással való versengés az euroatlanti integrációért folytatott küzdelemben, így a '90-es évek végéig stagnált a csoport aktivitása [1] Miután 2004-re mind a négy állam sikerrel abszolválta mind a NATO-hoz, mind az EU-hoz való csatlakozást, a tagállamok új alapokra helyezték V4-ek partnerségi tevékenységét. A négy ország miniszterelnökei Kroměříž városában zajló V4-es csúcstalálkozón egy új nyilatkozatot fogadtak el, mely felváltotta a csoport létrehozásáról szóló 1991-es dokumentumot. A V4-ek képviselői bejelentették, hogy elérték a korábban megfogalmazott célkitűzéseiket és kinyilvánították, hogy immár a NATO és az EU tagjaiként is eltökéltek az együttműködés folytatásában és elmélyítésében, és további összefogást gyakorolva elősegítik a régió fejlődését és érdekérvényesítő képességét. A 2010-es évek elejéig a miniszteri értekezletek és csúcstalálkozók témája elsősorban az Unió közös kül- és biztonságpolitikája, valamint a keleti bővítés volt. A visegrádi országok közös védelempolitikájával kapcsolatos, annak kezdeményezéséről szóló tárgyalások a 2010-es évek elején kezdődtek. A 2013. október 14-én Budapesten tartott csúcstalálkozó kiemelkedő jelentőséggel bírt, ugyanis először itt rögzítették nyilatkozat formájában, hogy az Észak-Atlanti Szövetség és az Európai Unió törekvéseivel összhangban a V4-ek közös védelempolitika megvalósítását tüzik ki célul, mely védelmi együttműködés aktívvá tételének érdekében a tagországok miniszterelnökei konkrét utasításokat fogalmaztak meg védelmi minisztereik felé, melyek tartalmi kivonatát a következő pontok alkotják:

- hosszú távú jövőkép felvázolása a közös védelmi együttműködési stratégiákról;

- kooperáció megerősítése a tagországok fegyveres erőinek kiképzése során és a gyakorlatok területén; -megerősített védelmi tervezési együttműködés kereteinek V4 szinten történő meghatározása, új védelmi együttműködési területekazonosítása. [2]

A budapesti csúcstalálkozót követő pár hónapon belül, 2015 márciusában a négy ország védelmi minisztere a V4-ek a közös védelempolitikai stratégia megerősítésére két dokumentumot is aláírt. A „Long Term Vision of the Visegrad Countries on Deepening their Defence Cooperation” címet viselő irat a tagországok hosszú távú elképzelését fogalmazza meg védelmi együttműködésük fokozásáról. Ennek alapján szükségesnek tekintik a védelmi ipar, a közös képességek fejlesztését, többnemzeti alakulatok létrehozását, közös védelmi célokat szolgáló eszközök, rendszerek beszerzését, az interoperabilitás kiszélesítését a közös oktatás, képzések és gyakorlatok által.

A másik dokumentum a „Framework for Enhanced Visegrad Defence Planning Cooperation” címet viselte, melyben megfogalmazzák azokat irányokat és tevékenységeket, melyek területén megvalósulhatnak a közös védelmi célokat szolgáló beszerzések és fejlesztések.

A fenti megállapodások és intenzív védelmi témájú találkozók eredményeit tekintve sikerek és kudarcok egyaránt elkönyvelhetők a tagországok ilyen téren való együttműködését illetően. Ami mindenképpen sikeresnek nyilvánítható az a többnemzeti alakulatok létrehozása, hiszen a V4 harccsoport 2019. július 1-től december 31-ig tartó intervallumban másodjára lépett készenlétbe. Szintén elismerésre méltó az oktatás és képzés területén történt aktív szerepvállalás. A közös kutatás-fejlesztési elképzelésekkel és beszerzésekkel kapcsolatos koncepciók eredménytelennek bizonyultak. Ezeken a területen a legnehezebb a kooperáció, mert vitális nemzeti védelemgazdasági érdekeket érint. [3]

\section{Haderőfejlesztési törekvések a V4 tagállamaiban a védelmi kiadások mértékének tekintetében}

Az elmúlt évtized második felétől a négy tagországban komoly lépéseket tettek a haderő fejlesztésének területén mind tárgyalások szintjén, mind már konkrét beszerzéseket illetően, ezenfelül a katonai kiképzés és oktatás területén is számos változást, változtatást irányoztak elő. A V4 államai többek között a hasonló történelmi, gazdasági és társadalmi múltból kifolyólag közel azonos problémákkal küzdenek a honvédelmi helyzetük, feladataik, katonai kötelezettségeik tekintetében mind 
saját nemzetük felé, mind pedig a NATO felé. Viszont eltérő nemzeti érdekeik miatt a biztonsággal kapcsolatos elképzeléseik fontossági skálája merőben más sorrendet mutat.

A visegrádi csoport államai közülterületre, gazdaságra, népességszámra vonatkozó adatait tekintve Lengyelország a legnagyobb. Az ország területe stratégiailag kiemelt jelentőségű, az EU és a NATO határállama, ebből kifolyólag a geopolitikai gondolkodás Lengyelország esetében a legmeghatározóbb. Lengyelország abból a szempontból szerencsés helyzetben van, hogy a rendszerváltás utáni időszakban, a NATO-hoz és EU-hoz történt csatlakozást követően ugyan jelentősen csökkentette a haderőfejlesztésre szánt összegeket, de nem építette le teljes mértékben a hadseregét, ezáltal sikerült viszonylag gyors ütemben újjáépíteni és modernizálni haderejét, mely folyamat még jelenleg is aktív státuszban van. A megújulás és fejlesztés, azok intenzitásának növelése ezen a területen már a Krím-félsziget Oroszország által történt 2014-ben lezajlott bekebelezése előtt is napirenden volt. Lengyelország 2009-óta átfogó védelmi reformot hajt végre, és az elmúlt évek során ennek megfelelően egyenletesen magasan - a GDP 2\%-a körül - tartotta védelmi kiadásait, de az orosz annexió után ez a folyamat érthető módon felgyorsult. 2030-ra a bruttó hazai termék 2,5\%-át tüzte ki célul honvédelmi kiadásokra fordítani. Napjainkra Lengyelország a hadsereg létszámát, felépítését tekintve egyértelműen a közép-kelet-európai régió vezető katonai hatalmává vált.

Szlovákia szintén az EU és a NATO perifériáján fekszik, így kiemelten fontos számára Ukrajna biztonsága. A NATO-elvárásoknak megfelelően Szlovákia is vállalta, hogy a költségvetés $2 \%$-át védelmi célokra fordítja, de ez az elmúlt évek során nem valósult meg. 2014 óta viszont folyamatosan növekvő tendenciát mutat a védelmi kiadásokra fordított összeg mértéke. A rendelkezésre álló adatok alapján 2014-ben a katonai költségvetés a GDP 1\%át tette ki, ez az arány a 2019. évre már 1,74\%-ra emelkedett. Csehország is komoly többletráfordítást irányoz elő az elkövetkezendő években a honvédelmi költségvetés területén, melyet az is alátámaszt, hogy az elmúlt fél évtizedben éves lebontásban nézve - a 2014-es 0,91\%-os értéket alapul véve -konzekvensen magasabb értéket mutatnak az erre irányuló kimutatások. 2019-ben már elérte a 1,19 \%-ot. [4] A cél Csehország esetében is, hogy a bruttó hazai termék kétszázalékos összegét tudják védelmi kiadásokra fordítani.

A történelmi múltat tekintve Magyarország előtt is még komoly feladatteljesítés áll a haderőfejlesz- tés területén. A '90-es évektől kezdve beindult egy permanens, hosszan tartó amortizációs folyamat a Magyar Honvédség haditechnikai eszközeit illetően, melynek eredményeképpen a 2000-es évek végére a magyar haderő teljesen elavult felszereléssel és fegyverzettel bírt, melyek jelentős része még a szovjet „örökség” volt. Ebben az időintervallumban a leépülés nemcsak a honvédség technikai felszereltségére vonatkozott, komolyan érintette a személyi állományt is. A 106/2007. (XII.6.) számú országgyülési határozat alapján az MH létszáma maximalizálva lett: 2007. december 31. után a honvédség létszáma nem haladhatta meg a 23950 föt, mely számmal az MH költségvetési létszáma elérte mélypontját. [5]

A 2010-es évektől ugyan mutatkozott erőfeszítés a modernizálás tekintetében, komolyabb eredmények mégis inkább csak az elmúlt három év során mutatkoztak. Az évtized második felétől növekvő tendenciát mutat a fejlesztés és az ebbe fektetett összeg mértéke mind a haditechnikai eszközállományt, mind pedig a katonai képességfejlesztést illetően. A „Zrínyi 2026” elnevezésű honvédelmi és haderőfejlesztési programot 2017 elején jelentették be, melynek keretén belül egy 10 éves periódust felölelve fogják a Magyar Honvédség teljes eszközparkját korszerűsíteni, a professzionális képzést erősíteni. A program megvalósulásával a kormány célja, hogy az MH a térség meghatározó haderejévé váljon.

2020-ban várható több olyan modern és professzionális technika megjelenése a honvédség eszközállományában, melyek beszerzését már korábbi tárgyalások útján rögzítette és jóváhagyta a magyar állam. Magyarország 2019. évi védelmi költségvetése 513 milliárd forint volt, a 2020. évre 103 milliárd forinttal többet, 616 milliárd forintot irányoztak elő, melyből 216 milliárd forint költhető fejlesztésekre. [6] Ez az összeg a GDP 1,17\%-a, mely még így is jelentősen elmarad a NATO által elvárt minimum 2\%-os aránytól, melynek teljesítésére a 2024. év lett célul kitüzve.

$\mathrm{Az}$ 1. ábra alapján látható a négy ország egymáshoz, illetve más NATO-tagállamokhoz viszonyított helyzete annak tekintetében, hogy az egyes államok védelmi költségvetése a nemzetek bruttó hazai termék hány százalékát tette ki a 2014. és a 2018-as évek összehasonlításában. A négy tagország eddigi haderőfejlesztési tevékenységeit és a védelmi célokra fordított összeg arányát tekintve megállapítható, hogy Lengyelország jelentősen kiemelkedik ezen a területen a másik három tagállamhoz viszonyítva. A védelmi kiadások az alábbi négy alapvető csoportra bonthatók: 


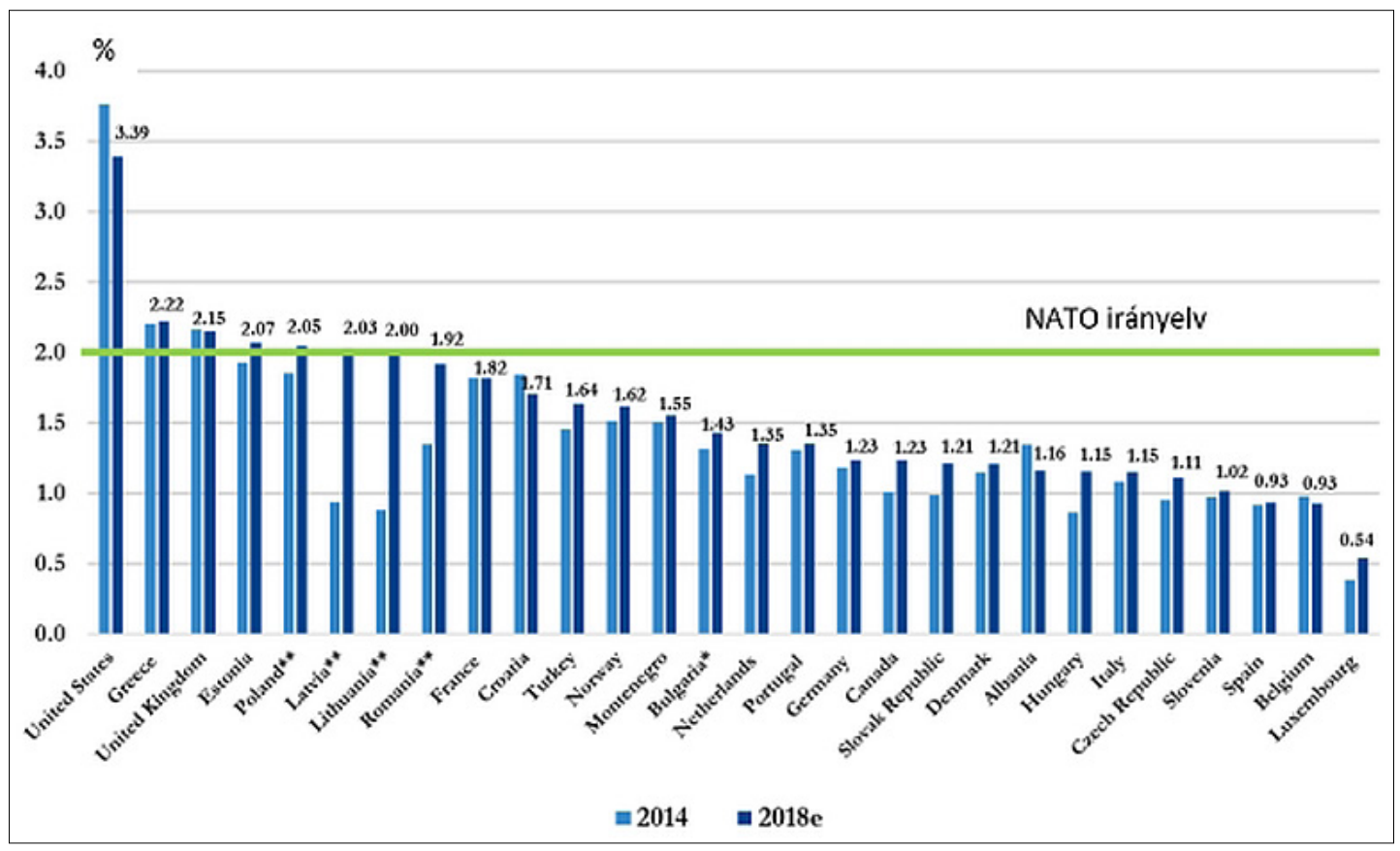

1. ábra. Védelmi kiadások a GDP arányában [7]

- haditechnikai eszközök

- személyi vonatkozású költségek

- infrastrukturális kiadások

- egyéb költségek. [8]

Kérdés azonban, hogy az adott államok milyen arányban hajtják végre a modernizáció részterületeit.

A katonai képességeket, illetve a haderő helyzetét, adottságait figyelembe véve a négy ország egymáshoz viszonyított helyzetéről a Global Firepower 2020-as [9] értékelése átfogó képet nyújt.

A rangsorban a 8 fő kategórián - emberi erőforrás, légierő, gépesített haderő, haditengerészet, természeti erőforrások, logisztika és földrajz - belül 45 egyedi tényezőt vesznek figyelembe az adott nemzet PowerIndex-pontszámának meghatározására. A legfrissebb adatok alapján a visegrádi csoport országai közül Lengyelország a 21. helyen szerepel, őt követi Csehország a 34. helyen, míg Magyarország az 54., Szlovákia pedig az 58. a listán szereplő 138 ország közül.

Többek között ezen adatok is alátámasztják, hogy a közös történelmi múlt ellenére a négy ország eltérő helyzetű haderővel rendelkezik. Eltérést mutat haderőinek nagysága, illetve különbözőséget mutat finanszírozásuk és fejlesztésük mértéke is. Ami viszont osztatlan célként detektálható mind a négy tagállam esetében, az a régi, szovjet haditech- nikai eszközök lecserélése. A NATO tekintetében a kompatibilitási és interoperabilitási képesség továbbra is garantált, arra azonban - figyelembe véve az adott országok ipari, gazdasági és politikai helyzetét - nincs lehetőség, hogy ezen fejlesztések során egységes felszereléseket, illetve gépparkot állítsanak fel a V4-ek. A haderőfejlesztésre irányuló védelmi kiadások jelentős eltérést mutatnak az egyes országok között, de az irányvonalat tekintve megállapítható, hogy az adott országok ilyen jellegű kiadásainak emelése kiemelt fontosságú.

\section{Következtetések}

Az új típusú biztonsági kihívásokat már csak modern, korszerü eszközökkel felszerelt, professzionálisan képzett állománnyal rendelkező haderő képes hatékonyan kezelni. A V4-ek tagországai az elmúlt évek során kiemelt hangsúlyt helyeztek a haderő-, illetve a képességfejlesztésre. A vizsgált négy állam - önmagához viszonyítva - a rendszerváltás óta talán napjainkban van a legmagasabb szinten hadereje fejlettségének és fejlesztésének mértékét illetően, és a jelenleg futó korszerüsítéssel kapcsolatos programok és tervek alapján ezt a folyamatot a 2030-as évek elejére tervezik lezárni. Jelen helyzetben az a kérdés, hogy az egyes tagállamok -az elkövetkezendő években a hazai és regionális politikai, illetve gazdasági életben bekövet- 
kezendő változások függvényében -milyen módon tudják fenntartani és betartani a fejlesztési programokban lefektetett és előirányzott terveket. A megváltozott biztonsági környezet nemcsak nemzeti, nemzetközi szintű erőfeszítéseket és összefogást is igényel. Az új típusú biztonsági kihívások kezelése új szemléletet, új hozzáállást, új megoldásokat és módszereket követel. A tömeghadsereg alkalmazása helyett a modern technológiai eszközök, azok szakszerű alkalmazása kerül előtérbe, ebből kifolyólag a katonák kiképzettsége, professzionalizmusa megkérdőjelezhetetlen fontossággal bír. A 21. század egyik jellegzetessége a haderők nemzetközi feladatokra történő felhasználásának korábban nem ismert felerősödése. [10] A V4-tagországok ennek tudatában viszik véghez a többéves ütemtervben meghatározott haderőfejlesztési folyamatokat, melyek megvalósítását elsősorban a nemzeti érdekek, a belső gazdasági és politikai helyzet és adottságok diktálta tényezők befolyásolják, de emellett érzékelhető, hogy a tagállamok odafigyelnek az egymás közötti együttmüködés egyensúlyának fenntartására a közép-kelet-európai térség stabil biztonságának érdekében.

\section{Köszönetnyilvánítás}

Az Innovációs és Technológiai Minisztérium ÚNKP19-3-III-NKE-47 kódszámú Új Nemzeti Kiválóság Programjának szakmai támogatásával készült.

\section{Szakirodalmi hivatkozások}

[1] Fodor M.: A visegrádi védelempolitika fejlödése, Biztonságpolitikai szakportál 2019.

https://biztonsagpolitika.hu/egyeb/a-visegradi-vedelempolitika-fejlodese (letöltve: 2020. március 1.).
[2] Visegrad Group, Budapest Joint Statement of the Visegrad Group Heads of Government On Strengthening the V4 Security and Defence Cooperation

http://www.visegradgroup.eu/calendar/2013/ budapest-joint-statement-140929 (letöltve: 2020.02.23.)

[3] Szenes Z.: Cél vagy eszköz? A visegrádi védelempolitika fejlődése (2). Honvédségi Szemle 2017/1. 3-23.

[4] Basic Data of the State Budget in Chapter of the Ministry of Defence in 1993-2018

http://www.army.cz/en/facts-file/defence-budget/ defence-budget-130198/ (letöltve: 2020.02.26.)

[5] Végh F.: Honvédségünk a rendszerváltástól napjainkig (2.). Honvédségi Szemle 2018/4. 3-18.

[6] Rekordnagyságú lesz a honvédelmi költségvetés 2020-ban

https://honvedelem.hu/cikk/rekordnagysagu-lesz-a-honvedelmi-koltsegvetes-2020-ban/ (letöltve: 2020.03.01.)

[7] Farkas T.: A védelmi tevékenységeket támogató MH Kormányzati Célú Elkülönült Hírközlő Hálózat fejlesztési lehetőségeinek vizsgálata a honvédelmi és haderőfejlesztési program (Zrínyi 2026) tükrében - Hazai/nemzetközi szakirodalmi összefoglaló. Hadtudományi Szemle 2019/4. 10.

[8] Farkas T.: A védelmi tevékenységeket támogató MH Kormányzati Célú Elkülönült Hírközlő Hálózat fejlesztési lehetőségeinek vizsgálata a honvédelmi és haderőfejlesztési program (Zrínyi 2026) tükrében - Hazai/nemzetközi szakirodalmi összefoglaló. Hadtudományi Szemle 2019/4. 5-16.

[9] 2020 Military Strength Ranking https://www.globalfirepower.com/countries-listing.asp (letöltve: 2020.03.01.)

[10] Gazdag F., Remek É.: A biztonsági tanulmányok alapjai. Dialóg Campus Kiadó, Budapest, 2018. 